\title{
Densely Planted Okra for Destructive Harvest: I. Effects on Yield
}

\author{
Yaying $\mathrm{Wu}^{1}$, Brian A. Kahn ${ }^{2}$, and Niels O. Maness ${ }^{3}$ \\ Department of Horticulture and Landscape Architecture, Oklahoma State \\ University, Stillwater, OK 74078-6027
}

John B. Solie ${ }^{3}$ and Richard W. Whitney ${ }^{4}$

Department of Biosystems and Agricultural Engineering, Oklahoma State University, Stillwater, OK 74078

\section{Kenneth E. Conway ${ }^{3}$ \\ Department of Entomology and Plant Pathology, Oklahoma State University, Stillwater, OK 74078}

Additional index words. Abelmoschus esculentus, mechanical harvest, plant population, spacing

\begin{abstract}
Okra [Abelmoschus esculentus (L.) Moench] was grown at various highly dense (HD) plant populations for destructive harvest, and compared with control plants grown at spacings of $90 \times 23 \mathrm{~cm}$ and harvested repeatedly by hand. Our objectives were to identify a HD plant arrangement and an optimum harvest timing to maximize marketable fruit yield per hectare with a single destructive harvest, and to evaluate the potential for regrowth of cut plants followed by one or more subsequent harvests. Within HD treatments, marketable fruit weight per hectare tended to increase as the plant population density increased. Spacings of $30 \times 30 \mathrm{~cm}$ and wider were not dense enough for the destructive harvest system due to a low marketable yield potential. Wide spacings did favor regrowth of cut plants in two experiments, but total marketable yields were still highest with the highest plant populations tested. Delaying destructive harvest until many overmature fruit were present did not consistently affect marketable fruit yield, but always decreased the proportion (by weight) of marketable fruit to total harvested fruit. Overall, percentages of marketable yield obtained by destructive harvests of plots with HD plant populations were low relative to the cumulative marketable yield from control plots. The lack of concentrated fruit set in okra remains a limiting factor for destructive harvest. However, the labor-saving potential of this system should stimulate further research.
\end{abstract}

Major food processing companies in the United States currently import almost all of their raw okra product because, as it is presently grown, the crop requires repeated hand harvests and thus has relatively high labor costs. Also, workers do not like to pick okra because the plants are physically irritating.

Economic considerations and phytosanitary concerns began to revive interest in the possibility of domestically produced, mechanically harvested okra in the early 1990s. Efforts to mechanize okra harvest had taken place at Clemson Univ. during the early 1970s. All work was done with conventional (91-102 $\mathrm{cm})$ between-row spacings. Some of the

Received for publication 21 Nov. 2002. Accepted for publication 11 Apr. 2003. Approved for publication by the Director, Oklahoma Agricultural Experiment Station. This research was supported in part under project $\mathrm{H}-2026$. The information given in this publication is for educational purposes only. Mention of a trademark, proprietary product, or vendor does not constitute a guarantee or warranty of the product, nor does it imply approval or disapproval to the exclusion of other products or vendors that may also be suitable.

${ }^{1}$ Former Graduate Research Assistant.

${ }^{2}$ Professor; to whom reprint requests should be addressed. E-mail: bakahn@okstate.edu

${ }^{3}$ Professor.

${ }^{4}$ Professor Emeritus. physical characteristics of okra related to mechanical harvesting were determined (Vick and Hood, 1970). Clemson researchers developed a multi-pass okra harvester designed to remove mature fruit and associated leaves from the stalk (Richardson, 1972). Successful commercialization of the harvester was not achieved even though automatic controls were added and the stripper mechanism was improved (Richardson and Craig, Jr., 1977). Plants inevitably were damaged by the multipass stripper system.

We hypothesized that a cultural system could be developed that would permit a destructive mechanical okra harvest. There were precedents with other vegetables, such as pickling cucumbers (Cucumis sativus L.) and processing-type tomatoes (Lycopersicon esculentum Mill.), which formerly were repeatedly harvested by hand but which now are primarily harvested destructively by machine (Ware and McCollum, 1980).

Destructive harvesting methods require sufficient numbers of horticulturally mature fruit to economically justify the mechanical harvest. Cantliffe and Phatak (1975) and Kretchman (1975) noted that plant population per unit area was a major factor determining yield, uniformity, and efficiency of harvest in mechanically harvested pickling cucumbers. Richardson (1977) indicated that more uniform okra plants would help reduce harvest losses associated with immature and overmature fruit production. Hermann et al. (1990) stated that the yield potential of an okra stand was highly dependent on the number of generative nodes formed per unit area. Many studies have been done in various locations on the response of okra to plant population based on repeated hand harvests. Results have shown that planting okra at higher population densities than those normally used reduced the crop duration (Fatokun and Chheda, 1983), concentrated fruit on the central flower stalk (McFerran et al., 1963), and increased the yield per hectare (Albregts and Howard, 1974; Fatokun and Chheda, 1983; McFerran et al., 1963; Patterson and Morelock, 1979; Shrestha, 1983). However, the optimum plant spacing to maximize yield and concentrate fruiting could not be ascertained because no method existed for harvesting okra planted in rows less than $60 \mathrm{~cm}$ wide.

The objectives of the present study were to: 1) identify a high density arrangement that concentrated flowering and maximized marketable fruit yield; 2) determine an optimum harvest timing to maximize marketable fruit yield per hectare with a single destructive harvest; and 3) evaluate the potential for regrowth of cut plants followed by one or more subsequent harvests. Responses of okra plant architecture to HD plant arrangements, and the implications of those responses for destructive mechanical harvest, are described elsewhere (Wu et al., 2003).

\section{Materials and Methods}

Six experiments were conducted during a 5-year period at the Vegetable Research Station in Bixby, Okla., on a Severn very fine sandy loam [coarse-silty, mixed (calcareous), thermic Typic Udifluvent] with an average organic C concentration of $4 \mathrm{~g} \cdot \mathrm{kg}^{-1}$ at a depth of 0 to 15 $\mathrm{cm}$. Each experiment occupied a different field at the station, and followed a rotational crop of soybean [Glycine $\max (\mathrm{L}$.) Merr.] grown and harvested in the previous year. Weeds were controlled with preplant-incorporated trifluralin [2,6-dinitro- $N, N$-dipropyl-4-(trifluoromethyl) benzenamine] at $560 \mathrm{~g} \cdot \mathrm{ha}^{-1}$ and by hoeing. Insects were controlled with malathion [O,O-dimethyl $S$-(1,2-dicarboxyethyl) phosphorodithioate] at $1.4 \mathrm{~kg} \cdot \mathrm{ha}^{-1}$ as needed. No foliar disease control products were applied. Overhead sprinkler irrigation was provided to supplement rainfall based on subjective observations of plants and soils.

'Clemson Spineless 80' okra was used exclusively, except in 1995 when four other cultivars were included. Seeds were sown with a vacuum-metering, ultranarrow-row precision planter developed by two of the authors (Solie and Whitney), except in 1996 when a handpushed seeder was used. Raw (non-enhanced) seed was used in all years except 1994, when seed that had been solid matrix primed was used. Priming was for $3 \mathrm{~d}$, after which seeds were allowed to dry back (for details, see Conway et al., 2001).

Expt. 1, 1992. The soil was prepared with a broadcast preplant-incorporated application of 
$51 \mathrm{~N}-22 \mathrm{P}-42 \mathrm{~K}\left(\mathrm{~kg} \cdot \mathrm{ha}^{-1}\right)$, plus trifluralin. Seeds were sown on 18 June 1992 in standard beds that were $2.1 \mathrm{~m}$ wide and not raised. The conventional spacing (control) was $90 \mathrm{~cm}$ between rows and $23 \mathrm{~cm}$ between plants within rows, with two rows per bed. Three HD arrangements were $15 \times 15 \mathrm{~cm}$ (10 rows per bed), 23 $\times 23 \mathrm{~cm}(7$ rows per bed), and $30 \times 30 \mathrm{~cm}(5$ rows per bed).

Plants in HD plots were destructively harvested by hand (simulating a mechanical harvest) on two sampling dates, 11 and 18 Sept. The early harvest was made when overmature fruits first were evident, while the second harvest was made a week later. At harvest, plants in HD plots were cut off with lopping shears at $\approx 15 \mathrm{~cm}$ above ground level, which was below the first branching node in almost every case. Cut plants were counted, removed from the field and defruited. Fruits were graded into immature (pods $<5 \mathrm{~cm}$ long), marketable, and overmature (pods $\geq 5 \mathrm{~cm}$ long with palpable fiber development) categories, counted and weighed. Plants in control plots were repeatedly and non-destructively hand harvested up to three times per week. A total of 20 harvests were made in control plots starting on 1 Sept. and ending on 16 Oct.

Asplit-block design with three replications was used. Main plots ( $8 \mathrm{~m}$ long) were spacings, arranged in randomized blocks, while subplots (4 m long) were harvest dates. The control did not have subplots; data areas in control rows were $2.5 \mathrm{~m}$ long.

Expt. 2, 1993. The soil was prepared with a broadcast preplant-incorporated application of $73 \mathrm{~kg} \cdot \mathrm{ha}^{-1}$ of $\mathrm{N}$, plus trifluralin. Adequate $\mathrm{P}$ and $\mathrm{K}$ were available from fertilization of previous trials. Seeds were sown on 17 June 1993 using the same spacings as in Expt. 1. Harvest procedures also were the same as in Expt. 1. Plants in HD plots were destructively harvested by hand on 3 and 23 Sept. Fruit set temporarily ceased following an initial harvest in control plots on 3 Sept. and then resumed. A total of 10 additional harvests were made in control plots starting on 24 Sept. and ending on 29 Oct. A split-block design with three replications was used, and plot sizes were identical to those in Expt. 1.

Expt. 3, 1994. The soil was prepared with a broadcast preplant-incorporated application of $36 \mathrm{~N}-16 \mathrm{P}-30 \mathrm{~K}\left(\mathrm{~kg} \cdot \mathrm{ha}^{-1}\right)$, plus trifluralin. Seeds were sown on 10 May 1994 using the same spacings as in Expt. 1. Plot sizes and overall layout in the field were similar to Expt. 1, but there were four replications and no subplots; instead, $4 \mathrm{~m}$ of each HD plot were used for an initial destructive hand harvest on 7 July (randomized complete-block design). Cut plants then regrew from their stumps to allow two subsequent destructive hand harvests. The first regrowth harvest was on $11 \mathrm{Aug}$. for the 30 $\times 30 \mathrm{~cm}$ treatment and on $22 \mathrm{Aug}$. for the 15 $\times 15 \mathrm{~cm}$ and $23 \times 23 \mathrm{~cm}$ treatments. All HD plots underwent a second regrowth harvest on 26 Sept. When regrowth occurred, branches were cut off at the level of the original stumps (that is, $\approx 15 \mathrm{~cm}$ above ground level). A total of 29 harvests were made in control plots starting on 1 July and ending on 26 Sept.
Expt. 4, 1994. Soil preparation was identical to that for Expt. 3. Seeds were sown on 24 May 1994 using the same spacings as in Expt. 1. Harvest procedures also were the same as in Expt. 1. Plants in HD plots were destructively harvested by hand on 26 Aug. and 6 Sept. A total of 20 harvests were made in control plots starting on 11 Aug. and ending on 13 Oct. A split-block design with four replications was used, and plot sizes were identical to those in Expt. 1.

Expt. 5, 1995. The soil was prepared with a broadcast preplant-incorporated application of $87 \mathrm{~N}-38 \mathrm{P}-72 \mathrm{~K}\left(\mathrm{~kg} \cdot \mathrm{ha}^{-1}\right)$, plus trifluralin. Seeds of 'Annie Oakley II', 'Clemson Spineless 80', 'Emerald', 'Green Best', and 'Lee' were sown on 15 June 1995 . Beds were $2.1 \mathrm{~m}$ wide and not raised. All cultivars were spaced at $25 \mathrm{~cm}$ between rows and $20 \mathrm{~cm}$ within rows, with six rows per bed. This study was designed to be a HD cultivar trial, so there were no conventionally spaced controls. Plots were $8 \mathrm{~m}$ long and arranged in randomized complete blocks, with four replications.

The intent was to use mechanical harvest in this study, but difficulties with the machine caused a delay. Therefore, plants in a 4-mlength of each plot $\left(8.4 \mathrm{~m}^{2}\right)$ were destructively harvested by hand on $11 \mathrm{Aug}$. following the same procedures as in Expt. 1. Plants were topdressed with urea to supply $45 \mathrm{~kg} \cdot \mathrm{ha}^{-1}$ of $\mathrm{N}$ on $23 \mathrm{Aug}$. A mechanical harvest occurred on 10 Oct. for the regrown plants in the $4 \mathrm{~m}$ of each plot previously harvested by hand. A sickle bar on the machine cut the plants at an average of $\approx 25 \mathrm{~cm}$ above ground level. A gathering reel deposited the cut plants onto a conveyer belt that transported them to a collection bin. The entire apparatus was mounted on a frame adapted from a self-propelled sprayer. Bins were unloaded at the end of each plot. Stalks were defruited by hand and pods were collected in bags for later grading and data recording.

Expt. 6, 1996. The soil was prepared with a broadcast preplant-incorporated application of $35 \mathrm{~kg} \cdot \mathrm{ha}^{-1}$ of $\mathrm{N}$, plus trifluralin. Adequate $\mathrm{P}$ and $\mathrm{K}$ were available from fertilization of previous trials. Seeds were sown on 17 May 1996 at an average rate of six seeds per 30

Table 1. Okra fruit yields from destructive hand harvests, Expt. 1, 1992. ${ }^{\mathrm{z}}$

\begin{tabular}{|c|c|c|c|c|c|c|c|}
\hline \multirow[b]{3}{*}{ Variable } & \multirow{3}{*}{$\begin{array}{c}\text { Plants per } \\
\text { ha } \times 10^{3}\end{array}$} & \multirow{2}{*}{\multicolumn{4}{|c|}{ Fruit fresh wt $\left(\mathrm{kg} \cdot \mathrm{ha}^{-1}\right)$}} & \multicolumn{2}{|c|}{ Harvested fruit } \\
\hline & & & & & & \multirow{2}{*}{$\begin{array}{l}\text { Percent by } \\
\text { wt of total } \\
\text { that was } \\
\text { marketable }\end{array}$} & \multirow{2}{*}{$\begin{array}{l}\text { Marketable } \\
\text { fresh wt as } \\
\text { a percent of } \\
\text { the control }\end{array}$} \\
\hline & & Immature & Marketable & Overmature & Total & & \\
\hline \multicolumn{8}{|l|}{$\underline{\text { Spacing }(\mathrm{cm})}$} \\
\hline $15 \times 15$ & $180.8 \mathrm{a}$ & 278 & $2523 \mathrm{a}$ & 6854 & $9655 \mathrm{a}$ & 27 & $26 \mathrm{a}$ \\
\hline $23 \times 23$ & $95.8 \mathrm{~b}$ & 231 & $1842 \mathrm{~b}$ & 7167 & $9240 \mathrm{a}$ & 23 & $19 \mathrm{~b}$ \\
\hline $30 \times 30$ & $50.0 \mathrm{c}$ & 138 & $1122 \mathrm{c}$ & 4369 & $5630 \mathrm{~b}$ & 24 & $11 \mathrm{c}$ \\
\hline Main effect & $* *$ & --- & $* *$ & NS & $*$ & NS & $* *$ \\
\hline \multicolumn{8}{|l|}{$\underline{\text { Harvest date }}$} \\
\hline 11 Sept. 1992 & 102.2 & 340 & 1503 & 3204 & 5047 & 30 & 15 \\
\hline 18 Sept. 1992 & 115.5 & 91 & 2154 & 9057 & 11302 & 19 & 22 \\
\hline Main effect & NS & --- & NS & $* *$ & $* *$ & $*$ & NS \\
\hline
\end{tabular}

If main effect of spacing is significant, mean separation in columns is by Duncan's multiple range test, $P \leq 0.05$. The spacing $\times$ harvest date interaction was significant $(P \leq 0.05)$ only for immature fruit weight. Means for the control $(90 \times 23 \mathrm{~cm})$ were $40.0 \times 10^{3}$ plants $/$ ha and $9838 \mathrm{~kg} \cdot \mathrm{ha}^{-1}$ of marketable fruit totaled from 20 harvests.

NS, ${ }^{*}, *$ Nonsignificant or significant at $P \leq 0.05$ or 0.01 , respectively. $\mathrm{cm}$ in standard beds that were $2.1 \mathrm{~m}$ wide and not raised. Seedlings were thinned on 10 June to achieve desired within-row spacings. The conventional spacing (control) was $90 \mathrm{~cm}$ between rows and $23 \mathrm{~cm}$ within rows, with rows per bed. Three HD arrangements were $25 \times 25 \mathrm{~cm}$ (six rows per bed), $38 \times 38$ $\mathrm{cm}$ (five rows per bed), and $50 \times 50 \mathrm{~cm}$ (four per $)$. These spacings were chosen to encourage branching following an initial destructive harvest. Plots were $6 \mathrm{~m}$ long and arranged in randomized complete blocks, with our replications.

Plants in the full $6 \mathrm{~m}$ of each HD plot were destructively harvested by hand on 15 July, using the same procedures as in Expt. 1. The supply $45 \mathrm{~kg} \cdot \mathrm{ha}^{-1}$ of $\mathrm{N}$ on 19 July. Cut plants regrew from their stumps, and a destructive hand harvest of the regrowth occurred on 26 Aug. The experiment was topdressed again with $45 \mathrm{~kg} \cdot \mathrm{ha}^{-1}$ of $\mathrm{N}$ on 6 Sept., but plants did not regrow quickly enough to allow another harvest. A total of 33 harvests were made in control plots starting on 9 July and ending on 25 Sept.

Statistical analysis. Each experiment was analyzed separately. Data were evaluated by analysis of variance procedures. Duncan's multiple range test was used for mean separation. When harvest date was a variable, significant east significant differ for differences between subplot treatments for different main plot treatments).

\section{Results}

Expt. 1. Marketable fruit weights increased as plant spacing decreased from $30 \times 30 \mathrm{~cm}$ to $15 \times 15 \mathrm{~cm}$, with no effect of harvest date as the harvest date was delayed in all spacings. This led to a high total fruit weight at the late harvest, and caused marketable fruit to make up a smaller proportion of total harvested fruit weight at late harvest than at early harvest. Marketable fruit accounted for $\approx 25 \%$ of the total harvested fruit weight from destructive harvests 


\section{Crop Production}

Table 2. Okra fruit yields from destructive hand harvests, Expt. 2, 1993. ${ }^{\mathrm{z}}$

\begin{tabular}{|c|c|c|c|c|c|c|c|}
\hline \multirow[b]{3}{*}{ Variable } & \multirow{3}{*}{$\begin{array}{r}\text { Plants per } \\
\text { ha } \times 10^{3}\end{array}$} & & & & & \multicolumn{2}{|c|}{ Harvested fruit } \\
\hline & & & Fruit fresh w & $\left(\mathrm{kg} \cdot \mathrm{ha}^{-1}\right)$ & & \multirow{2}{*}{$\begin{array}{l}\text { Percent by } \\
\text { wt of total } \\
\text { that was } \\
\text { marketable }\end{array}$} & \multirow{2}{*}{$\begin{array}{l}\text { Marketable } \\
\text { fresh wt as } \\
\text { a percent of } \\
\text { the control }\end{array}$} \\
\hline & & Immature & Marketable & Overmature & Total & & \\
\hline \multicolumn{8}{|l|}{ Spacing $(\mathrm{cm})$} \\
\hline $15 \times 15$ & $175.0 \mathrm{a}$ & 52 & 377 & 1830 & 2259 & 25 & 6 \\
\hline $23 \times 23$ & $99.4 \mathrm{~b}$ & 42 & 294 & 1900 & 2236 & 17 & 4 \\
\hline $30 \times 30$ & $53.6 \mathrm{c}$ & 39 & 203 & 1128 & 1369 & 16 & 3 \\
\hline Main effect & $* *$ & NS & NS & NS & NS & NS & NS \\
\hline \multicolumn{8}{|l|}{$\underline{\text { Harvest date }}$} \\
\hline 3 Sept. 1993 & 108.3 & 10 & 309 & 772 & 1091 & 30 & 4 \\
\hline 23 Sept. 1993 & 110.3 & 78 & 273 & 2467 & 2819 & 9 & 4 \\
\hline Main effect & NS & ** & NS & $*$ & $*$ & $* *$ & NS \\
\hline
\end{tabular}

${ }^{2}$ If main effect of spacing is significant, mean separation in columns is by Duncan's multiple range test, $P \leq 0.05$.

No significant $(P \leq 0.05)$ spacing $\times$ harvest date interactions were evident for the variables shown. Means for the control $(90 \times 23 \mathrm{~cm})$ were $37.0 \times 10^{3}$ plants $/$ ha and $7202 \mathrm{~kg} \cdot \mathrm{ha}^{-1}$ of marketable fruit totaled from 11 harvests.

NS, ${ }^{*}, * *$ Nonsignificant or significant at $P \leq 0.05$ or 0.01 , respectively.

Table 3. Cumulative okra fruit yields from three destructive hand harvests, Expt. 3, 1994. ${ }^{2}$

\begin{tabular}{|c|c|c|c|c|c|c|c|c|}
\hline \multirow{3}{*}{$\begin{array}{l}\text { Spacing } \\
(\mathrm{cm})\end{array}$} & \multirow{3}{*}{$\begin{array}{l}\text { Plants per } \\
\text { ha } \times 10^{3}\end{array}$} & \multirow{2}{*}{\multicolumn{4}{|c|}{ Fruit fresh wt $\left(\mathrm{kg} \cdot \mathrm{ha}^{-1}\right)$}} & \multicolumn{3}{|c|}{ Harvested fruit } \\
\hline & & & & & & \multirow{2}{*}{$\begin{array}{l}\text { Percent by } \\
\text { wt of total } \\
\text { that was } \\
\text { marketable }\end{array}$} & \multirow{2}{*}{$\begin{array}{l}\text { Marketable } \\
\text { fresh wt as } \\
\text { a percent of } \\
\text { the control }\end{array}$} & \multirow{2}{*}{$\begin{array}{l}\text { Contribution } \\
\text { of regrowth } \\
\text { (\% of total } \\
\text { marketable } \\
\text { yield) }\end{array}$} \\
\hline & & Immature & Marketable & Overmature & Total & & & \\
\hline $15 \times 15$ & $125.3 \mathrm{a}$ & 439 & $4247 \mathrm{a}$ & $6184 \mathrm{a}$ & $10871 \mathrm{a}$ & $39 \mathrm{~b}$ & 15 & 37 \\
\hline $23 \times 23$ & $88.1 \mathrm{~b}$ & 417 & $3574 \mathrm{~b}$ & $5768 \mathrm{a}$ & $9760 \mathrm{ab}$ & $37 \mathrm{~b}$ & 12 & 46 \\
\hline $30 \times 30$ & $48.5 \mathrm{c}$ & 345 & $3615 \mathrm{~b}$ & $4044 \mathrm{~b}$ & 8004 b & $45 \mathrm{a}$ & 13 & 59 \\
\hline \multicolumn{9}{|c|}{ Main effect of spacing } \\
\hline Spacing & $* *$ & NS & $*$ & $*$ & $*$ & $* *$ & NS & NS \\
\hline
\end{tabular}

with all three spacings. However, marketable fruit weight as a percentage of the control increased as plant spacing decreased from $30 \times$ $30 \mathrm{~cm}$ to $15 \times 15 \mathrm{~cm}$ (Table 1$)$. The spacing $\times$ harvest date interaction was significant $(P \leq$ 0.05 ) only for immature fruit weight. The interaction LSD $\left(98 \mathrm{~kg} \cdot \mathrm{ha}^{-1}\right)$ showed that immature fruit weights differed among spacings only at the early harvest (11 Sept.). At early harvest, immature fruit weights from plants spaced at 15 $\times 15 \mathrm{~cm}\left(438 \mathrm{~kg} \cdot \mathrm{ha}^{-1}\right)$ and at $23 \times 23 \mathrm{~cm}(383$ $\mathrm{kg} \cdot \mathrm{ha}^{-1}$ ) were greater than those from plants spaced at $30 \times 30 \mathrm{~cm}\left(200 \mathrm{~kg} \cdot \mathrm{ha}^{-1}\right)$.

Expt. 2. Although plant populations differed, spacing treatments resulted in no significant yield differences (Table 2). Both immature and overmature fruit weights increased at late harvest (23 Sept.), reducing the proportion (by weight) of marketable fruit to total harvested fruit as compared with the early harvest (3 Sept.) (Table 2).

Expt. 3. Increasing the plant population density from $30 \times 30 \mathrm{~cm}$ to $23 \times 23 \mathrm{~cm}$ did not increase marketable fruit weight and increased overmature fruit weight, so that the proportion (by weight) of marketable fruit to total harvested fruit was decreased (Table 3). Increasing the plant population density from $23 \times 23 \mathrm{~cm}$ to $15 \times 15 \mathrm{~cm}$ increased marketable fruit weight, but other measures of yield were unaffected. The proportion (by weight)

Table 4. Okra fruit yields from destructive hand harvests, Expt. 4, 1994. ${ }^{\mathrm{z}}$

\begin{tabular}{|c|c|c|c|c|c|c|c|}
\hline \multirow[b]{3}{*}{ Variable } & \multirow{3}{*}{$\begin{array}{l}\text { Plants per } \\
\text { ha } \times 10^{3}\end{array}$} & \multirow{2}{*}{\multicolumn{4}{|c|}{ Fruit fresh wt $\left(\mathrm{kg} \cdot \mathrm{ha}^{-1}\right)$}} & \multicolumn{2}{|c|}{ Harvested fruit } \\
\hline & & & & & & \multirow{2}{*}{$\begin{array}{l}\text { Percent by } \\
\text { wt of total } \\
\text { that was } \\
\text { marketable }\end{array}$} & \multirow{2}{*}{$\begin{array}{l}\text { Marketable } \\
\text { fresh wt as } \\
\text { a percent o } \\
\text { the control }\end{array}$} \\
\hline & & Immature & Marketable & Overmature & Total & & \\
\hline \multicolumn{8}{|l|}{$\underline{\text { Spacing }(\mathrm{cm})}$} \\
\hline$\overline{15 \times 15}$ & $205.8 \mathrm{a}$ & 178 & 1817 & $6855 \mathrm{a}$ & $8850 \mathrm{a}$ & 24 & 9 \\
\hline $23 \times 23$ & $99.8 \mathrm{~b}$ & 129 & 1655 & $7188 \mathrm{a}$ & 8972 a & 21 & 8 \\
\hline $30 \times 30$ & $56.8 \mathrm{c}$ & 112 & 1318 & $5208 \mathrm{~b}$ & $6638 \mathrm{~b}$ & 25 & 7 \\
\hline Main effect & $* *$ & --- & NS & $*$ & $*$ & NS & NS \\
\hline \multicolumn{8}{|l|}{ Harvest date } \\
\hline$\overline{26 \text { Aug. } 1994}$ & 125.2 & 218 & 1299 & 2932 & 4449 & 31 & 7 \\
\hline 6 Sept. 1994 & 116.5 & 61 & 1894 & 9902 & 11857 & 16 & 10 \\
\hline Main effect & NS & --- & $*$ & $* *$ & $* *$ & $* *$ & * \\
\hline
\end{tabular}

${ }^{2}$ If main effect of spacing is significant, mean separation in columns is by Duncan's multiple range test, $P \leq 0.05$.

The spacing $\times$ harvest date interaction was significant $(P \leq 0.05)$ only for immature fruit weight. Means for the control $(90 \times 23 \mathrm{~cm})$ were $36.7 \times 10^{3}$ plants $/$ ha and $19,916 \mathrm{~kg} \cdot \mathrm{ha}^{-1}$ of marketable fruit totaled from 20 harvests.

Ns, *,** Nonsignificant or significant at $P \leq 0.05$ or 0.01 , respectively.

of marketable fruit from regrown stems to total marketable fruit tended to increase as plant population density decreased, but the trend was nonsignificant. Regrown stems made an important contribution to overall marketable yield (Table 3).

Expt. 4. There was a nonsignificant trend towards an increase in marketable fruit weight as plant population density increased (Table 4). Although this trend was nonsignificant, it helped balance out the greater weight of overmature fruit from plants spaced at $15 \times 15 \mathrm{~cm}$ and at $23 \times 23 \mathrm{~cm}$ compared with plants spaced at $30 \times 30 \mathrm{~cm}$, so that marketable fruit as a proportion of total harvested fruit weight was similar among spacing treatments (Table 4). Delaying the destructive harvest from 26 Aug. to 6 Sept. increased marketable fruit weight, but also greatly increased overmature fruit weight. As a result, the proportion (by weight) 


\begin{tabular}{|c|c|c|c|c|c|c|}
\hline \multirow[b]{3}{*}{ Cultivar } & & & & & \multicolumn{2}{|c|}{ Harvested fruit } \\
\hline & \multicolumn{4}{|c|}{ Fruit fresh wt $\left(\mathrm{kg} \cdot \mathrm{ha}^{-1}\right)$} & \multirow{2}{*}{$\begin{array}{l}\text { Percent by } \\
\text { wt of total } \\
\text { that was } \\
\text { marketable }\end{array}$} & \multirow{2}{*}{$\begin{array}{l}\text { Avt wt per } \\
\text { marketable } \\
\text { fruit } \\
\text { (g/fruit) }\end{array}$} \\
\hline & Immature & Marketable & Overmature & $\operatorname{Total}^{y}$ & & \\
\hline Annie Oakley II & 118 & 3025 & $3317 \mathrm{~b}$ & $6664 \mathrm{~b}$ & $46 \mathrm{~b}$ & $17 \mathrm{~b}$ \\
\hline Clemson Spineless 80 & 104 & 2371 & $1598 \mathrm{c}$ & $4373 \mathrm{c}$ & $54 \mathrm{a}$ & $23 \mathrm{a}$ \\
\hline Green Best & 100 & 2700 & $6027 \mathrm{a}$ & $9262 \mathrm{a}$ & $29 \mathrm{c}$ & $18 \mathrm{~b}$ \\
\hline \multicolumn{7}{|c|}{ Main effect of cultivar } \\
\hline Cultivar & NS & NS & $* *$ & $* *$ & $* *$ & $*$ \\
\hline
\end{tabular}

${ }^{2}$ If main effect of cultivar is significant, mean separation in columns is by Duncan's multiple range test, $P \leq 0.05$.

${ }^{y}$ Includes cull fruit weights, which averaged $312 \mathrm{~kg} \cdot \mathrm{ha}^{-1}$ and did not differ among cultivars.

ws, ${ }^{*, * *}$ Nonsignificant or significant at $P \leq 0.05$ or 0.01 , respectively.

Table 6. Cumulative okra fruit yields from two destructive hand harvests, Expt. 6, 1996. ${ }^{\mathrm{z}}$

\begin{tabular}{|c|c|c|c|c|c|c|c|c|}
\hline \multirow{3}{*}{$\begin{array}{l}\text { Spacing } \\
(\mathrm{cm})\end{array}$} & \multirow{3}{*}{$\begin{array}{c}\text { Plants per } \\
\text { ha } \times 10^{3}\end{array}$} & \multirow{2}{*}{\multicolumn{4}{|c|}{ Fruit fresh wt $\left(\mathrm{kg} \cdot \mathrm{ha}^{-1}\right)$}} & \multicolumn{3}{|c|}{ Harvested fruit } \\
\hline & & & & & & \multirow{2}{*}{$\begin{array}{l}\text { Percent by } \\
\text { wt of total } \\
\text { that was } \\
\text { marketable }\end{array}$} & \multirow{2}{*}{$\begin{array}{l}\text { Marketable } \\
\text { fresh wt as } \\
\text { a percent of } \\
\text { the control }\end{array}$} & \multirow{2}{*}{$\begin{array}{l}\text { Contribution } \\
\text { of regrowth } \\
\text { (\% of total } \\
\text { marketable } \\
\text { yield) }\end{array}$} \\
\hline & & Immature & Marketable & Overmature & Total $^{y}$ & & & \\
\hline $25 \times 25$ & $114.3 \mathrm{a}$ & 357 & $1723 \mathrm{a}$ & $5159 \mathrm{a}$ & $7445 \mathrm{a}$ & $23 \mathrm{a}$ & $9 \mathrm{a}$ & $38 \mathrm{c}$ \\
\hline $38 \times 38$ & $63.5 \mathrm{~b}$ & 350 & $1379 \mathrm{~b}$ & 5827 a & 7818 a & $18 \mathrm{~b}$ & $7 \mathrm{~b}$ & $46 \mathrm{~b}$ \\
\hline $50 \times 50$ & $38.1 \mathrm{c}$ & 327 & $874 \mathrm{c}$ & 4208 b & $5615 \mathrm{~b}$ & $16 \mathrm{~b}$ & $5 \mathrm{c}$ & $62 \mathrm{a}$ \\
\hline \multicolumn{9}{|c|}{ Main effect of spacing } \\
\hline Spacing & $* *$ & NS & $* *$ & $* *$ & $* *$ & $*$ & $* *$ & $* *$ \\
\hline
\end{tabular}

'If main effect of spacing is significant, mean separation in columns is by Duncan's multiple range test, $P \leq 0.05$. Means for
the control $(90 \times 23 \mathrm{~cm})$ were $44.4 \times 10^{3} \mathrm{plants} / \mathrm{ha}$ and $18,962 \mathrm{~kg} \cdot \mathrm{ha}^{-1}$ of marketable fruit totaled from $33 \mathrm{harvests}$. ${ }^{\mathrm{y}}$ Includes cull fruit weights, which averaged $225 \mathrm{~kg} \cdot \mathrm{ha}^{-1}$ and did not differ among spacings.

Ns, ${ }^{*}, * *$ Nonsignificant or significant at $P \leq 0.05$ or 0.01 , respectively.

of marketable fruit to total harvested fruit was cut almost in half compared with the 26 Aug. harvest (Table 4$)$. The spacing $\times$ harvest date interaction was significant $(P \leq 0.05)$ only for immature fruit weight. The interaction LSD (41 $\mathrm{kg} \cdot \mathrm{ha}^{-1}$ ) showed that immature fruit weights differed among spacings only at the early harvest (26 Aug.). At early harvest, immature fruit weights from plants spaced at $15 \times 15 \mathrm{~cm}(278$ $\mathrm{kg} \cdot \mathrm{ha}^{-1}$ ) were greater than those from plants spaced at $23 \times 23 \mathrm{~cm}\left(199 \mathrm{~kg} \cdot \mathrm{ha}^{-1}\right)$ and at 30 $\times 30 \mathrm{~cm}\left(177 \mathrm{~kg} \cdot \mathrm{ha}^{-1}\right)$.

Expt. 5. 'Emerald' and 'Lee' did not produce adequate stands and were dropped from the study. The remaining three cultivars did not differ in stand and averaged $101.9 \times 10^{3}$ plants per ha. These three cultivars differed in total fruit weight following the $11 \mathrm{Aug}$. harvest due to differences in overmature fruit weight (Table 5). Marketable fruit accounted for over half of the total harvested fruit weight of 'Clemson Spineless 80'. This cultivar also had the heaviest individual marketable fruits (Table 5).

Marketable fruit yields were very low from the mechanical harvest on 10 Oct. (average of $76 \mathrm{~kg} \cdot \mathrm{ha}^{-1}$ ), and there were no significant differences among the three cultivars. Therefore, further data from this harvest are not presented here. Details are available in $\mathrm{Wu}$ et al. (2003).

Expt. 6. The $50 \times 50 \mathrm{~cm}$ spacing resulted in $38.1 \times 10^{3}$ plants per ha, which was less than the control population of $44.4 \times 10^{3}$ plants per ha $(P \leq 0.05$; analysis not presented). Weight of immature fruit was unaffected by HD spacing (Table 6). Marketable fruit weights increased as plant spacing decreased from $50 \times 50 \mathrm{~cm}$ to $25 \times 25 \mathrm{~cm}$. The $50 \times 50 \mathrm{~cm}$ spacing resulted in the lowest overmature and total pod weights. Marketable fruit accounted for more of the total harvested fruit weight from destructive harvests with the $25 \times 25 \mathrm{~cm}$ spacing than with lower densities of spacing. Marketable fruit weight as a percent of the control increased as plant spacing decreased from $50 \times 50 \mathrm{~cm}$ to $25 \times 25 \mathrm{~cm}$. The proportion (by weight) of marketable fruit from regrown stems to total marketable fruit increased as plant population density decreased (Table 6).

\section{Discussion}

The general tendency was that marketable fruit weight per hectare increased as the plant population density increased in all experiments, although the trend was not always statistically significant. This is in agreement with observed responses of other vegetables where the fruits are consumed, such as tomato (Nicklow and Downes, 1971) and pickling cucumber (Cantliffe and Phatak, 1975). In the case of Expt. 2(1993), yields were limited by heat and drought despite periodic irrigation. One might speculate that $\mathrm{N}$ nutrition could limit the yield potential of densely planted okra, but this does not appear to be the case (Kahn et al., 2003). Hermann et al. (1990) proposed that the yield response of okra to increased plant populations would saturate between 10 and 20 plants per $\mathrm{m}^{2}$ due to interplant competition and floral abortion. Albregts and Howard (1976) grew four okra cultivars at 22, 65, and 130 plants per $\mathrm{m}^{2}$ and found the number of pods per $\mathrm{m}^{2}$ was unaffected by plant population due to interplant competition. We could not determine an optimum plant population density because stands varied between experiments. However, spacings of $30 \times 30 \mathrm{~cm}$ and wider were not dense enough for the destructive harvest system due to a low marketable yield potential. Wide spacings did favor regrowth of cut plants in Expts. 3 and 6, but total marketable yields were still highest with the highest plant populations in these two experiments (Tables 3 and 6).

In our experiments, marketable yields were not consistently affected by the timing of the initial destructive harvest. However, delaying harvest until many overmature fruit were present always increased the total harvested fruit weight and decreased the proportion (by weight) of marketable fruit to total harvested fruit (Tables 1, 2, 4). These responses would make a destructive harvest less efficient by increasing the load of fruit to be sorted and decreasing the proportional yield of marketable fruit. Timing of harvest also would be complicated by choice of cultivar. We focused our studies on the open-pollinated 'Clemson Spineless 80' based on processor preferences for its pod shape and relatively inexpensive seed. Hybrids were included for comparison in Expt. 5, and the high weight of overmature fruit (especially for 'Green Best') on the 11 Aug. harvest date suggested that these cultivars became reproductive earlier than 'Clemson Spineless 80' (Table 5).

Overall, percentages of marketable yield obtained by destructive harvests of high-population plots were low relative to the cumulative marketable yield from control plots (Tables 1,2, 
$3,4,6)$. The best result occurred when a single destructive harvest of the $15 \times 15 \mathrm{~cm}$ plots on 18 Sept. 1992 yielded $33 \%$ of the marketable fruit weight obtained by 20 hand harvests over 6.5 weeks in the control (only overall means are shown in Table 1). However, the labor-saving potential makes further studies worthwhile. In contrast to fresh market production, where a continuous supply of raw product is necessary due to perishability, a processor can take in a more concentrated volume of raw product, preserve it by canning or freezing, and create an inventory of processed product for distribution. At this time, the authors agree with Düzyaman (1997) that in okra, "the lack of concentrated fruit set limits mechanization possibilities." The same could have been said of pickling cucumbers 50 years ago, and advances in plant breeding, growth regulators, and cultural practices overcame the limitations.

\section{Literature Cited}

Albregts, E.E. and C.M. Howard. 1974. Response of okra to plant density and fertilization. HortScience 9:400.

Albregts, E.E. and C.M. Howard. 1976. Response of four okra cultivars on mulched beds to plant density. HortScience 11:242.
Cantliffe, D.J. and S.C. Phatak. 1975. Plant population studies with pickling cucumbers grown for once-over harvest. J. Amer. Soc. Hort. Sci. 100:464-466.

Conway, K.E., R. Mereddy, B.A. Kahn, Y. Wu, S.W. Hallgren, and L. Wu. 2001. Beneficial effects of solid matrix chemo-priming in okra. Plant Dis. 85:535-537.

Düzyaman,E. 1997. Okra: Botany and horticulture,p. 41-72. In: J. Janick (ed.). Horticultural reviews, vol. 21. Wiley, New York.

Fatokun, C.A. and H.R. Chheda. 1983. The influence of population density on yield and yield components of okra [Abelmoschus esculentus (L.) Moench]. Acta Hort. 123:273-281.

Hermann, M., M. Makadji, and H.J. Daunicht. 1990. Effect on intra-row spacing on time course of growth and fruit yield of okra. Scientia Hort. 45:37-48,

Kahn, B.A., Y. Wu, N.O. Maness, J.B. Solie, and R.W. Whitney. 2003. Densely planted okra for destructive harvest: III. Effects of nitrogen nutrition. HortScience 38:1370-1372.

Kretchman, D.W. 1975. Plant population-cultivarnitrogen relations to yield and returns from mechanical harvest of pickling cucumbers. Res. Summary Ohio Agr. Res. and Dev. Ctr. 81:25-27.

McFerran, J., G.A. Bradley, and H.L. Bowden. 1963. Production of Clemson Spineless okra. Ark. Farm Res. 12(2):10
Nicklow, C.W. and J.D. Downes. 1971. Influence of nitrogen, potassium and plant population on the maturity of field seeded tomatoes for once-over harvest. J. Amer. Soc. Hort. Sci. 96:46-49.

Patterson, W.K. and T.E. Morelock. 1979. Effects of variety and spacing on okra yield. Ark. Farm Res. 28(6):8.

Richardson, M.K. 1972. Mechanical harvesting of okra. Trans. Amer. Soc. Agr. Eng. 15: 1021-1023.

Richardson, M.K. 1977. Plant growth configurations which affect the mechanical harvesting of okra. Trans. Amer. Soc. Agr. Eng. 20:420-422.

Richardson, M.K. and J.T. Craig, Jr. 1977. Automatic controller simulation for mechanical okra harvesting. Trans. Amer. Soc. Agr. Eng. 20:413-419.

Shrestha, G.K. 1983. Effects of spacing and nitrogen fertilizer on 'Pusa Sawani' okra (Abelmoschus esculentus) in Nepal. Expt. Agr. 19:239-242.

Vick, W.L. and C.E. Hood. 1970. Certain physical characteristics of okra which relate to mechanical harvesting. ASAE Paper No. 70-810. Amer. Soc. Agr. Eng. (ASAE), St. Joseph, Mo.

Ware, G.W. and J.P. McCollum. 1980. Producing vegetable crops. 3rd ed. Interstate, Danville, Ill.

Wu, Y., B.A. Kahn, N.O. Maness, J.B. Solie, R.W. Whitney, and K.E. Conway. 2003. Densely planted okra for destructive harvest: II. Effects on plant architecture. HortScience 38: 1365-1369. 